\title{
TENDINȚE DE DEZVOLTARE A PIEȚEI FORȚEI DE MUNCĂ ÎN MUN. CHIȘINĂU
}

\author{
Valentina COTELNIC ${ }^{\odot}$, cercetător științific, \\ Centrul de Cercetări Demografice al INCE, Republica Moldova \\ DOI: https://doi.org/10.36004/nier.cdr.2019.14-17
}

JEL Classification: J21, J68.

În acest articol este prezentată analiza indicatorilor principali ce caracterizează situația actuală a pieței forței de muncă, precum și estimată eficiența măsurilor active de stimulare a ocupări forței de muncă orientate pentru diminuarea numărului șomerilor aflați în evidență la agenția teritorială pentru ocuparea forței de muncă din mun. Chișinău. Obiectivul principal al studiului a fost determinarea eficienței serviciilor de ocupare a forței de muncă realizate de către Agenția Națională pentru Ocuparea Forței de Muncă (ANOFM) în baza indicatorilor de apreciere a ponderii beneficiarilor de serviciile respective, angajați în câmpul muncii, precum și cheltuielilor aferente pentru acordarea serviciilor de ocupare a unui beneficiar angajat. Concomitent a fost comparată dinamica acestor indicatori în perioada anilor 2014-2018. Estimarea eficienței serviciilor prestate a fost efectuată atât în termeni de cost, cât și în termeni de rezultat.

Concluzionând necesitatea îmbunătățirii situației pe piața muncii din mun. Chişinău, au fost elaborate propuneri de perfecționare a măsurilor active ținând cont de cerințele pieței muncii actuale.

Cuvinte-cheie: forța de muncă, șomajul, măsurile active de ocupare, eficiența măsurilor active.

The analysis of the main indicators characterizing the current situation of labour market was carried out in this article. In addition, the effectiveness of active labour-boosting measures aimed at reducing the number of unemployed people in the Territorial Employment Agency of Chisinau were assessed. The main objective of the study was to determine the efficiency of employment services provided by the National Employment Agency (NEA) based on indicators for assessing the share of beneficiaries of those services, employed in the labour field and related expenses for the provision of employment services of an employed beneficiary. Additionaly, the dynamics of these indicators was compared during the years 2014-2018. The estimation of the efficiency of the provided services was carried out both in terms of cost and outcome.

Concluding the need to improve the situation in labour market of Chisinau, proposals for the improvement of active measures have been developed taking into account the requirements of the current labour market.

Key words: labour force, unemployment, active employment measures, efficiency of active measures.

Piața muncii în ansamblul ei cuprinde sistemul integral de relaţii cu referință la cererea și oferta forței de muncă la toate nivelele. Scopurile principale și social importante ale reglementării pieței muncii constituie reducerea maximă a nivelului șomajului, menținerea corelării optime a cererii și ofertei de forță de muncă.

Ocuparea forței de muncă reprezintă o problemă importantă atât din punct de vedere economic, cât și social. Dimensiunea economică este determinată de faptul că, cu cât nivelul de ocupare este mai înalt, cu atât este mai mare nivelul de dezvoltare economică a țării. Dimensiunea socială se caracterizează prin faptul că orice ocupare oferă persoanei apte de muncă un venit și, prin urmare, un nivel de trai mai înalt. Pornind de la aceste afirmații, de-a lungul timpului, ocuparea

\footnotetext{
๑ Valentina Cotelnic, vcotelnic@gmail.com
} 
forței de muncă a constituit o problemă majoră atât pentru cercetători, cât și pentru persoane politice, abilitate să ia decizii adecvate și eficiente care să îmbunătătească acest indicator [3].

Procesul continuu de reducere a populației și îmbătrânirea demografică contribuie la diminuarea numărului populației active şi îmbătrânirea forței de muncă, generând astfel o creștere a ratei de dependență a persoanelor vârstnice, dar şi a raportului de dependenţă economică.

Analizând structura populației active pe grupe de vârste pe regiuni, se constată evidente tendințe de îmbătrânire a acesteia. Ponderea cea mai mare este deținută de persoane cu vârste de peste 45 de ani. În anul 2018, ratele de activitate şi de ocupare pentru populația în vârsta aptă de muncă la nivel de țară au înregistrat o ușoară creștere, atingând valorile de $43,3 \%$ și respectiv $42,0 \%$ faţă de nivelul de $41,2 \%$ pentru rata de activitate şi $39,6 \%$ pentru rata de ocupare în anul 2014.

Analiza șomajului este una dintre cele mai dificile şi mai responsabile pârți a analizei economice. Șomajul corelează strâns cu emigrarea forței de muncă peste hotare. Emigrarea servește ca un factor ce atenuează presiunile asupra pieței muncii şi reduce în mod substanțial rata șomajului. În anul 2018 numărul șomerilor a scăzut cu 13,2 mii față de anul 2017, rata șomajului rămânând la un nivel de 3,0\%, în mun. Chișinău acest indicator a fost în descreștere cu 1,2 p.p. comparativ cu anul 2014. Principala explicaţie de menținere a șomajului la cote relativ mici este că populația are posibilitatea emigrării. Doar în anul 2018 plecate peste hotare la lucru sau în căutarea unui loc de muncă au fost 130,0 mii persoane, ce constituie $20,8 \%$ din populația inactivă, ceea ce poate fi explicată prin lipsa locurilor de muncă și condițiile de muncă atractive și bine plătite atât în Republica Moldova, câț și în mun. Chișinău.

Distribuția populației economic active şi ocupate din mun. Chișinău în funcție de sex, în anul 2018 se prezintă astfel: $55,1 \%$ bărbați şi 41,0\% femei pentru populaţia economic activă (față de $45,8 \%$ bărbaţi şi $41,0 \%$ femei total pe țară) şi 44,2\% bărbaţi şi 40,0\% femei pentru populaţia ocupată (comparativ cu 49,6\% bărbați și 50,3\% femei în mediu pe Republica Moldova), pe piața muncii din mun. Chișinău o pondere mai mare le revine bărbaților, atât în populația activă, cât și în cea ocupată [2].

In mun. Chișinău, ratele de ocupare a femeilor și a bărbaților cu vârsta de 15-24 de ani reprezintă încă un aspect care trebuie menționat, acestea înregistrând în anul 2018 valori de 26,2\% femei fiind în creștere față de anul 2017 cu 3,2 p.p. și respectiv 30,7\% - bărbați, înregistrând o creștere față de anul 2017 cu 6,3 p.p.

Ponderea persoanelor de vârsta a treia în capitalul uman din țară (lucrătorii din categoriile de vârsta de 65 de ani și peste), în ultimii ani, înregistrează creșteri în totalul populației ocupate, înregistrând în anul 2018 valori de 13,5\%, fiind în creștere faţă de 2017 cu 0,5 p.p., pe când în mun. Chișinău în ultimii doi ani acest indice înregistrează valoarea de 7,2\%, fiind în creștere față de anul 2014 cu 0,9 p.p.

Piața muncii este considerată drept cea mai socială şi cea mai reglementată dintre piețe. Pentru realizarea eficientă a politicilor pe piața forței de muncă au fost adoptate o serie de acte normative în vederea perfecționării cadrului regulatoriu de promovare a politicilor active, în special în domeniul orientării, instruirii, integrării sau reintegrării profesionale, susținerii în problemele ce țin de carieră, antrenării șomerilor la lucrări publice etc.

Analiza situației curente a pieței forței de muncă din mun. Chișinău, prin evidențierea tendințelor dinamicii indicatorilor principali privind forța de muncă, este efectuată prin prisma posibilităților de integrare pe piața muncii a diferitor categorii de populație, având o gamă largă de locuri libere/vacante și nivelul de pregătire profesională a populației aflate în statut de șomer.

Conform datelor Agenției pentru ocuparea forței de muncă din mun. Chișinău, în anul 2018 numărul șomerilor oficial înregistrați a constituit 2919 persoane, micşorându-se cu 4111 șomeri, sau 29,0 la sută comparativ cu anul 2017, fiecare al doilea fiind disponibilizat de la unitățile economice. Din numărul total de șomeri, ponderea cea mai mare - $51,2 \%$ revine bărbaților, iar 48,8 la sută o constituie femeile. 
- Locuri vacante, mii locuri

" Numărul șomerilor înregistrați total, mii pers.

- Şomerii plasați în câmpul muncii, mii pers.

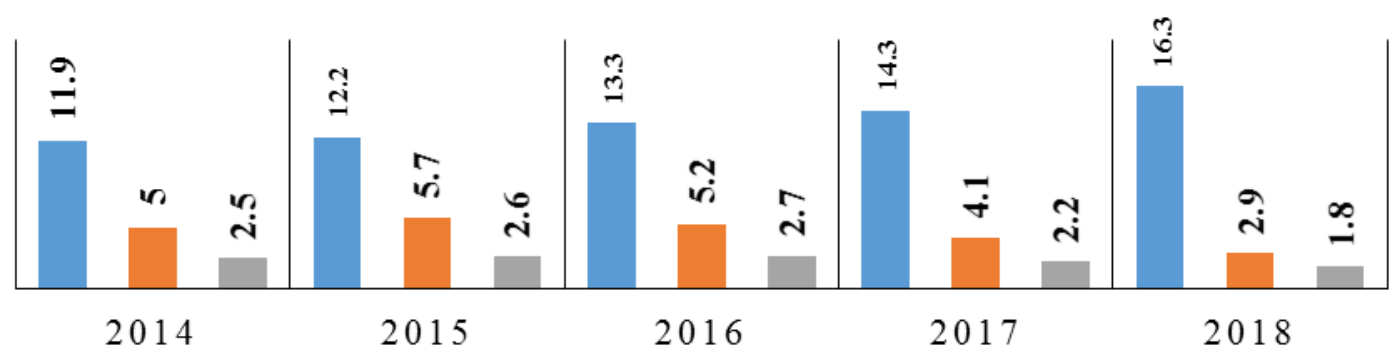

Figura 1. Dinamica locurilor vacante, șomerilor înregistrați și plasați în anii 2014-2018 Sursa: ANOFM, www.anofm.md

Din numărul total al șomerilor înregistrați, plasaţi în câmpul muncii au fost $60,5 \%$, cu 7,4 \% mai mult față de anul 2017. Circa 4,1\% din șomerii înregistrați de la începutul anului au beneficiat de ajutor de șomaj, mărimea medie a căruia a fost în luna decembrie 2018 de 2342,79 lei, fiind în creștere cu 15,8 \% faţă de anul precedent. La un loc liber de muncă, anunţat de către agenții economici, reveneau în medie 2,5 șomeri, față de 4,5 șomeri în anul 2017. În anul 2018 structura șomerilor după vârstă a fost neuniformă: $20,2 \%$ din numărul șomerilor sunt persoane tinere cu vârsta cuprinsă între 16 - 29 ani, iar 27,5\% - persoane în vârstă de peste 50 de ani, pe când ponderea cea mai mare 52,2\% - revine celor cu vârsta cuprinsă între 30-49 ani.

Distribuția în funcție de cel mai înalt nivel de educație arată că în perioada anilor 2014-2018 se evidențiază creșterea ponderii șomerilor plasați în câmpul muncii cu studii primare şi gimnaziale de la 16,0\% în anul 2014, la 24,5\% în anul 2018, pe când cei cu studii liceale și medii de specialitate se menține la același nivel de cca 24,0\%, fiind urmați de cei cu studii medii de specialitate și studii superioare, care înregistrează o ușoară descreștere de 3,0\% faţă de anul 2014 [1].

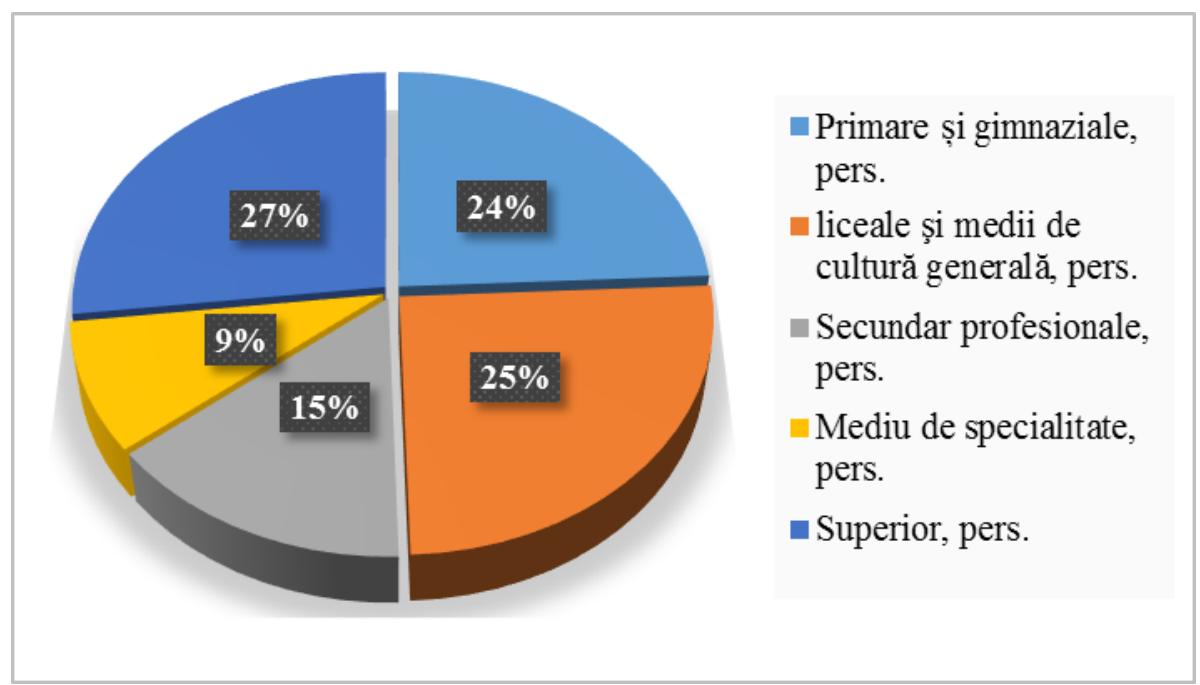

Figura 2. Structura șomerilor înregistrați conform nivelului de studii în anul 2018 Sursa: ANOFM, www.anofm.md

Analizând caracteristicile șomerilor după nivelul de educație, reiese că pe parcursul ultimilor ani se atestă o reducere a calității forței de muncă, ceea ce se demonstrează și prin faptul că persoanele fără calificare înregistrate reprezintă o pondere de cca $63 \%$ din numărul total al 
șomerilor înregistrați și doar 37\% le dețin șomerii calificați. În mun. Chișinău, posturile cu cea mai mare carență de personal calificat sunt cele de profesori, medici, asistenţi medicali și sociali, inginer programator, urmate de cele de IT etc. Alte posturi care resimt o lipsă de personal calificat sunt cele de ingineri telecomunicații, specialist în instituțiile publice (270 unități) etc,. În anul 2018 au fost înregistrate 16,3 mii locuri libere de muncă, dintre care pentru persoanele cu nivel de instruire superior şi mediu de specialitate constituind $40,1 \%$, din numărul total de locuri vacante înregistrate (în domeniul sănătății - 149 (medici, asistenței medicali); inginer -55 , specialist în activitatea financiară, economică sau comercială - 128 etc.).

Conform legislației în vigoare, măsurile active care vizează creșterea șanselor de ocupare a persoanelor aflate în căutarea unui loc de muncă includ serviciile de informare și consiliere profesională, de mediere a muncii, de calificare şi recalificare. Programele de formare profesională asigură calificarea, recalificarea și perfecționarea șomerilor și a persoanelor aflate în căutarea unui loc de muncă, ținând cont de cererea pieței muncii și asigurându-le acestora creșterea și diversificarea competenţelor profesionale pentru a se integra mai uşor pe piaţa muncii. Nivelul şi calitatea ocupării forței de muncă depind, în mare măsură, de formarea ei profesională, care generează gradul de adaptabilitate şi angajabilitate pe piața muncii, deoarece forța de muncă bine instruită şi calificată poate fi competitivă pe piața muncii [4].

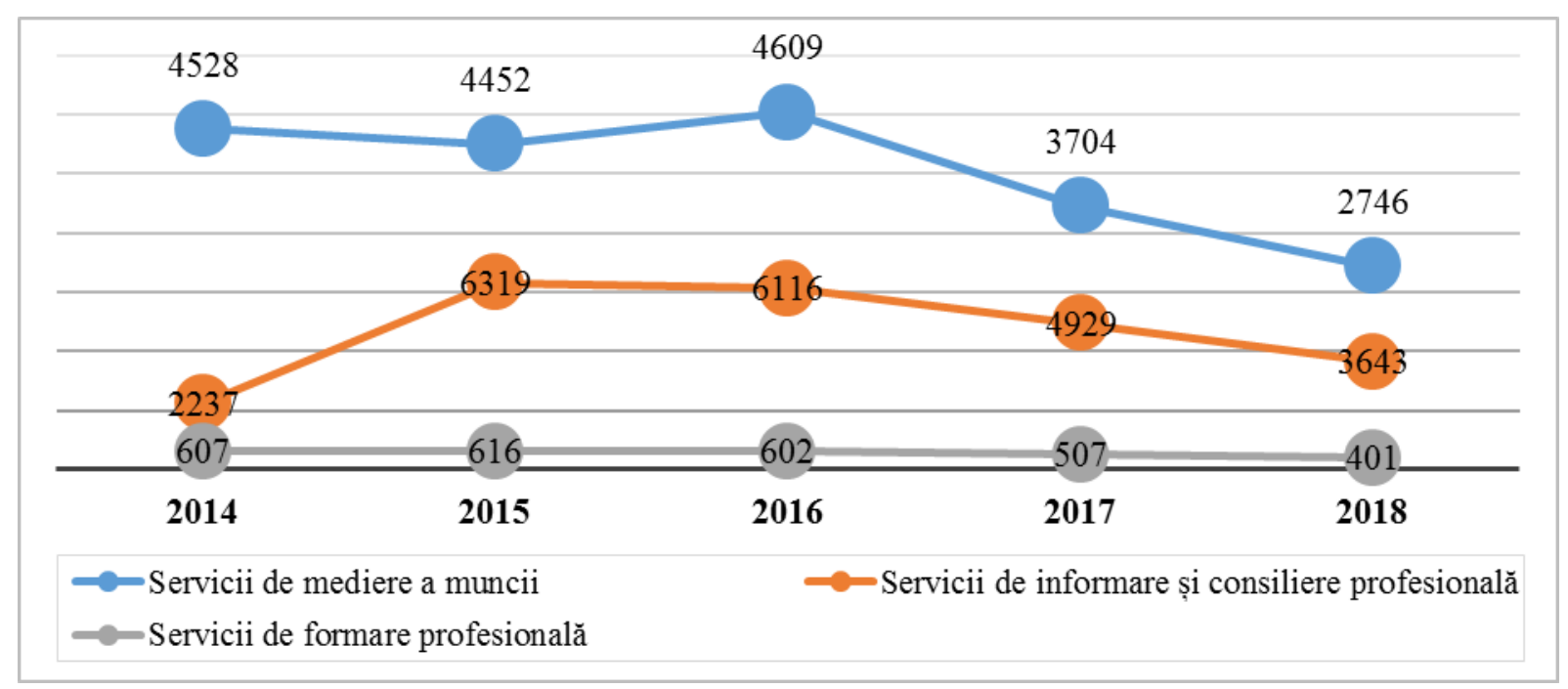

Figura 3. Structura serviciilor de mediere a muncii acordate șomerilor în anii 2014 - 2018

Sursa: ANOFM, www.anofm.md

Pe parcursul anilor 2014-2018, dezvoltarea sistemului de acordare a serviciilor de mediere a muncii, de formare profesională și de informare și consiliere profesională a fost neuniformă. Observăm că în anii 2014-2018 s-a redus semnificativ numărul beneficiarilor de servicii de mediere a muncii - cu 1782 persoane, respectiv cu 39\%, pe când serviciile de informare și consiliere profesională a crescut vertiginos - de la 2237 persoane în 2014 la 6116 persoane în 2016, ca mai apoi eficiența acestor servicii să fie redusă semnificativ, în anul 2018 doar 3643 persoane au beneficiat de aceste servicii. O situație similară a fost înregistrată și la serviciile de formare profesională, unde numărul beneficiarilor a diminuat anul, în anul 2018 doar 401persoane (607 în anul 2014) au beneficiat de servicii de formare profesională, înregistrând cel mai scăzut nivel de eficiență în perioada analizată. În același timp, numărul persoanelor beneficiare de pregătirea profesională, care au fost încadrate în câmpul muncii grație acestor servicii, a crescut cu $11,2 \%$ în anul 2018 față de anul 2017, atingând valoarea de 93,8\% (Fig. 4.). 


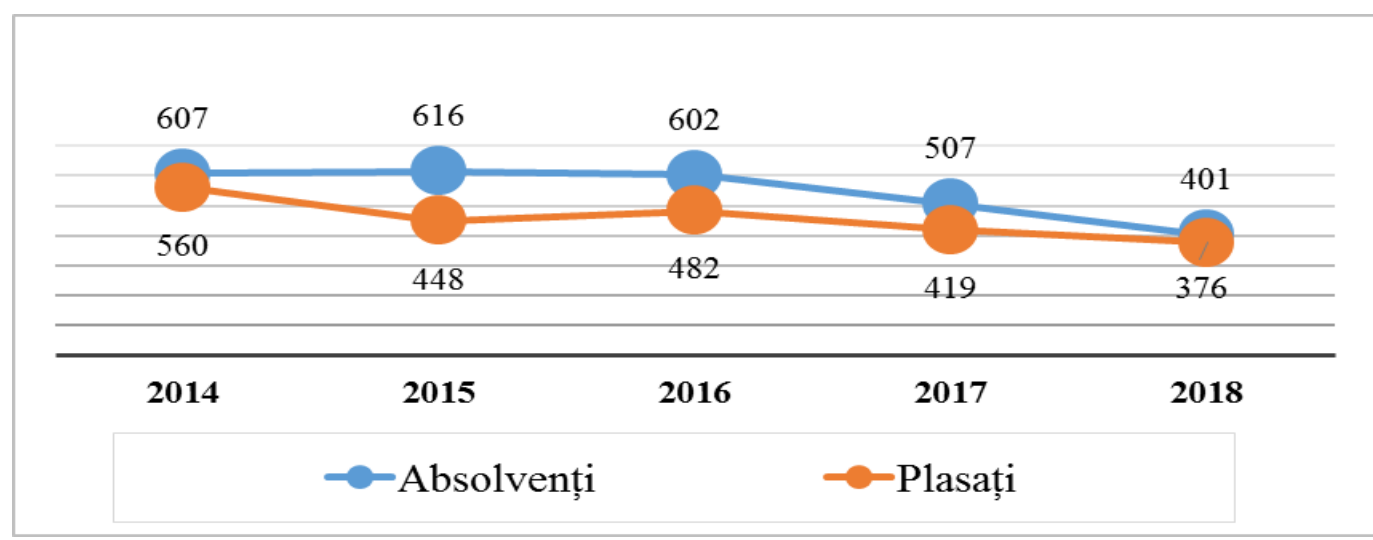

Figura 4. Structura șomerilor plasați în câmpul muncii după absolvirea cursurilor Sursa: ANOFM, www.anofm.md

Cota înaltă de plasare în câmpul muncii a absolvenților cursurilor de pregătire profesională de la $92,3 \%$ în anul 2014 la $93,8 \%$ în anul 2018- indică o orientare profesională inițială corectă, fapt ce confirmă că persoana a ținut cont de tendințele pieței muncii și a ales profesia solicitată.

ANOFM, fiind instituţia centrală a serviciului public de ocupare, care exercită atribuții în domeniul medierii muncii, în scopul corelării și apropierii cererii și ofertei de muncă, informării privind situația pe piaţa muncii, realizării și supravegherii executării măsurilor active de ocupare a forței de muncă, are ca obiectiv important și asigurarea eficienței activității sale, ceea ce ne permite de a aprecia raționalitatea utilizării resurselor financiare alocate măsurilor active, în special serviciului de mediere, de informare și consiliere, precum și de formare profesională [5].

La etapa actuală de dezvoltare, creșterea eficienței ocupării forței de muncă rămâne a fi una din principalele condiții de asigurare a creșterii economice din țară. Pentru a efectua analiza eficienței serviciilor de ocupare a forței de muncă, realizate de către ANOFM, au fost aplicați indicatorii de apreciere a ponderii beneficiarilor de serviciile respective, angajaţi în câmpul muncii, precum și cheltuielile aferente pentru acordarea serviciilor de ocupare a unui beneficiar angajat și a fost comparată dinamica acestora în anii 2014 - 2018. Prin urmare, estimarea eficienţei serviciilor prestate a fost efectuată atât în termeni de cost, cât și în termeni de rezultat.

Rezultatele calculelor indicatorilor de cost şi eficienţa măsurilor active de ocupare a forţei de muncă întreprinse de către ANOFM, precum și evidențierea oportunităţilor de sporire a nivelului de ocupare sunt prezentate în Tabelul 1.

Tabelul 1. Eficiența serviciilor de ocupare a populației realizate de ANOFM, anii 2014-2018

\begin{tabular}{|l|c|c|c|c|c|}
\hline \multicolumn{1}{|c|}{ Indicatori } & $\mathbf{2 0 1 4}$ & $\mathbf{2 0 1 5}$ & $\mathbf{2 0 1 6}$ & $\mathbf{2 0 1 7}$ & $\mathbf{2 0 1 8}$ \\
\hline Mumărul beneficiarilor de servicii de mediere & 25045 & 25935 & 28054 & 26178 & 23245 \\
\hline $\begin{array}{l}\text { Numărul persoanelor angajate în urma } \\
\text { serviciilor de mediere }\end{array}$ & 16366 & 16780 & 17654 & 16648 & 14702 \\
\hline Cheltuieli ce țin de medierea muncii (mii, lei) & 283,3 & 277,3 & 257,8 & 285,3 & 255,7 \\
\hline $\begin{array}{l}\text { Eficiența serviciilor de mediere: procentul } \\
\text { persoanelor plasate în câmpul muncii din } \\
\text { numărul total al beneficiarilor, \% }\end{array}$ & 65,3 & 64,7 & 62,9 & 63,6 & 63,2 \\
\hline $\begin{array}{l}\text { Cheltuieli pe 1 persoană angajată în urma } \\
\text { serviciilor de mediere (lei / pers.) }\end{array}$ & 17,31 & 16,53 & 14,60 & 17,14 & 17,39 \\
\hline $\begin{array}{c}\text { INFORMARE ȘI CONSILIERE } \\
\text { PROFESIONALA A }\end{array}$ & & & & & \\
\hline $\begin{array}{l}\text { Numărul beneficiarilor de servicii de } \\
\text { informare și consiliere profesională }\end{array}$ & 26336 & 65392 & 70647 & 63022 & 52782 \\
\hline $\begin{array}{l}\text { Numărul persoanelor angajate în urma } \\
\text { măsurilor de informare şi consiliere }\end{array}$ & 6408 & 14674 & 15845 & 14690 & 12996 \\
\hline
\end{tabular}




\begin{tabular}{|l|c|c|c|c|c|}
\hline profesională & & & & \\
\hline $\begin{array}{l}\text { Cheltuieli pentru informarea şi consilierea } \\
\text { profesională (mii, lei) }\end{array}$ & 33,6 & 35,2 & 35,7 & 79,9 & 53,5 \\
\hline $\begin{array}{l}\text { Eficiența serviciilor de informare şi } \\
\text { consiliere profesională: procentul } \\
\text { persoanelor plasate în câmpul muncii din } \\
\text { numărul total al beneficiarilor, \% }\end{array}$ & 24,3 & 22,4 & 22,4 & 23,3 & 24,6 \\
\hline $\begin{array}{l}\text { Cheltuieli pe 1 persoană angajată în urma } \\
\text { serviciilor de informare şi consiliere } \\
\text { profesională (lei / 1 pers.) }\end{array}$ & 5,24 & 2,40 & 2,25 & 5,44 & 4,11 \\
\hline \multicolumn{1}{|c|}{ FORMARE PROFESIONALĂ } & & & & & \\
\hline $\begin{array}{l}\text { Persoane care au absolvit cursurile de formare } \\
\text { profesională de la începutul anului }\end{array}$ & 2884 & 2979 & 2902 & 2628 & 2214 \\
\hline $\begin{array}{l}\text { Numărul persoanelor angajate în urma } \\
\text { formării profesionale }\end{array}$ & 2492 & 1586 & 2598 & 2233 & 2012 \\
\hline $\begin{array}{l}\text { Cheltuieli pentru formarea profesională (mii, } \\
\text { lei) }\end{array}$ & 9972,7 & 10575,6 & 9655,2 & 8763,7 & 5092,1 \\
\hline $\begin{array}{l}\text { Eficiența serviciilor de formare profesională: } \\
\text { procentul persoanelor plasate în câmpul } \\
\text { muncii din numărul total al absolvenților, \% }\end{array}$ & 86,4 & 53,2 & 89,5 & 85,0 & 90,9 \\
\hline $\begin{array}{l}\text { Cheltuieli pe 1 persoană angajată în urma } \\
\text { serviciilor de formare profesională (lei /1 } \\
\text { pers.) }\end{array}$ & 4001,89 & 6668,10 & 3716,40 & 3924,6 & 2530,7 \\
\hline
\end{tabular}

Sursa: Calcule efectuate de autor în baza datelor prezentate de către ANOFM

Serviciile de mediere a muncii, în perioada analizată, înregistrează o reducere a cheltuielilor de la 283,3 mii lei în anul 2014, ajungând la 255,7 mii lei (cu 10\%) în 2018 concomitent s-a micșorat și numărul persoanelor angajate grație medierii muncii - cu 10,2 p.p., fiind angajate în anul 2018 doar 14702 persoane faţă de 16366 persoane în anul 2014. Pe când cheltuielile de mediere pentru 1 persoană angajată rămân practic la același nivel, înregistrând în anul 2014 valoarea de 17,31 lei, respectiv în anul 2018 acest indice era de 17,39 lei, doar în anul 2016 a fost cu 17,8p.p. mai mic față de anul 2018.

Din Tabelul 1. observăm că formarea profesională presupune cele mai înalte cheltuieli (5092,1 mii lei în 2018), în pofida faptului că sunt înregistrate cele mai înalte cheltuieli, comparativ cu 2014 ele au diminuat cu 4880,6 mii lei, respectiv cu 49,1\%. Concomitent, esenţial s-au diminuat și cheltuielile pentru 1 persoană angajată în urma formării profesionale - cu 1471,19 lei. În același timp, ponderea persoanelor plasate în câmpul muncii din totalul beneficiarilor de formare profesională s-a redus cu 19,3 p.p. Cu toate acestea, formarea profesională înregistrează în continuare cele mai înalte rezultate în angajarea în câmpul muncii a persoanelor ce au urmat un curs de pregătire profesională.

Evidențiem că metodica aprecierii eficienței în termeni de cost implementată până în prezent de ANOFM se efectuează prin raportarea cheltuielilor la un beneficiar al serviciilor de ocupare a forței de muncă (realizată doar pentru uz intern, nefiind reflectată în rapoartele de activitate oficiale).

Pentru relevarea mai justă a eficienței serviciilor de ocupare, este necesar de calculat cheltuielile pentru fiecare beneficiar angajat în câmpul muncii ca urmare a serviciilor de ocupare prestate, deoarece cheltuielile destinate beneficiarilor neangajați în câmpul muncii pot fi considerate irosite.

Așadar, formula utilizată la calculul eficienței serviciilor de ocupare a populației se exprimă în felul următor (în lei/pentru o persoană): 
Cheltuielile 1 angajat în urma serviciilor de ocupare a populației (de mediere, de informare și consiliere profesională, de formare profesională) $=$ Cheltuielile totale destinate serviciului respectiv / $\mathbf{N}$ beneficiari angajați în urma obținerii serviciului respectiv.

Determinarea nivelului eficienței serviciilor de ocupare a forței de muncă în plan teritorial a fost realizat prin cercetările desfăşurate în baza datelor mun. Chișinău, mun. Bălți și ale raioanelor Soroca, (regiunea de Nord), Hâncești, Orhei (regiunea Centru), Cahul (regiunea de Sud). Rezultatele calculelor sunt prezentate în Tabelele 2., 3. și 4. Din Tabelul 2. observăm că eficiența serviciilor de mediere, în termeni de rezultat, este puțin mai înaltă în mun. Bălți, comparativ cu mun. Chișinău, iar în profil teritorial, în perioada anilor 2014-2018 a fost înregistrată o eficiență mai înaltă în raioanele Orhei și Soroca. Ponderile de plasare în câmpul muncii înregistrate peste 100\% se datorează deficiențelor în sistemul de evidență - o parte a persoanelor angajate în urma serviciilor de informare și consiliere profesională a fost atribuite la beneficiari angajați în urma serviciilor de mediere. Eficiența în termeni de cost variază semnificativ. Cele mai mici costuri au fost înregistrate în anul 2016 în raionul Soroca - 6,26 lei pe un beneficiar angajat în câmpul muncii. De asemenea, observăm că pe parcursul anilor 2014-2018, în mun. Chișinău au fost înregistrate cele mai înalte costuri per beneficiar angajat în urma serviciilor de mediere.

\section{Tabelul 2. Eficiența serviciilor privind medierea muncii}

\begin{tabular}{|l|c|c|c|c|c|c|c|c|c|c|}
\hline & \multicolumn{4}{|c|}{$\begin{array}{c}\text { Ponderea persoanelor plasate } \\
\text { in câmpul muncii din numărul total } \\
\text { al beneficiarilor, \% }\end{array}$} & \multicolumn{5}{c|}{$\begin{array}{c}\text { Cheltuieli pe 1 persoană angajată } \\
\text { în urma serviciilor de mediere } \\
\text { (lei / 1 pers.) }\end{array}$} \\
\cline { 2 - 13 } & $\mathbf{2 0 1 4}$ & $\mathbf{2 0 1 5}$ & $\mathbf{2 0 1 6}$ & $\mathbf{2 0 1 7}$ & $\mathbf{2 0 1 8}$ & $\mathbf{2 0 1 4}$ & $\mathbf{2 0 1 5}$ & $\mathbf{2 0 1 6}$ & $\mathbf{2 0 1 7}$ & $\mathbf{2 0 1 8}$ \\
\hline Nivel național & 65 & 65 & 63 & 64 & 63 & 17,31 & 16,53 & 14,60 & 17,14 & 19,21 \\
\hline Mun. Chișinău & 56 & 59 & 58 & 59 & 30 & 43,90 & 47,51 & 52,18 & 58,20 & 61,36 \\
\hline Mun. Bălți & 61 & 61 & 67 & 57 & 36 & 23,18 & 9,17 & 8,48 & 9,55 & 10,27 \\
\hline pe raioane: & & & & & & & & & & \\
\hline Soroca & 87 & 87 & 77 & 94 & 110 & 8,64 & 6,79 & 6,26 & 6,45 & 6,62 \\
\hline Cahul & 125 & 78 & 44 & 62 & 71 & 9,09 & 17,21 & 6,49 & 10,80 & 18,63 \\
\hline Orhei & 63 & 55 & 79 & 253 & 119 & 8,67 & 11,58 & 9,79 & 11,38 & 16,26 \\
\hline Hâncești & 23 & 27 & 51 & 62 & 89 & 13,91 & 13,49 & 23,31 & 24,15 & 25,82 \\
\hline
\end{tabular}

Sursa: Elaborat de autor în baza datelor ANOFM

Eficiența în termeni de rezultat a serviciilor de informare și consiliere profesională se prezintă cea mai înaltă în anul 2017-2018 în raionul Cahul (Tabelul 3.). În același timp, considerăm că valoarea de 45,0\% ar putea fi depășită dacă evidența beneficiarilor de servicii ar fi corectă. Eficiența în termeni de cost a fost cea mai înaltă înregistrată în anul 2016 în mun. Chișinău - 0,91 lei per beneficiar angajat, iar în anii 2017-2018 în raioanele Orhei și Hâncești au fost înregistrate cele mai înalte costuri per beneficiar angajat în urma serviciilor de informare și consiliere profesională. 
Tabelul 3. Eficiența serviciilor privind informarea și consilierea profesională

\begin{tabular}{|c|c|c|c|c|c|c|c|c|c|c|}
\hline & \multicolumn{5}{|c|}{$\begin{array}{c}\text { Ponderea persoanelor plasate } \\
\text { în câmpul muncii din numărul total } \\
\text { al beneficiarilor, } \%\end{array}$} & \multicolumn{5}{|c|}{$\begin{array}{c}\text { Cheltuieli pe } 1 \text { persoană angajată în urma } \\
\text { serviciilor de informare şi } \\
\text { consiliere profesională } \\
\text { (lei / } 1 \text { pers.) }\end{array}$} \\
\hline & 2014 & 2015 & 2016 & 2017 & 2018 & 2014 & 2015 & 2016 & 2017 & 2018 \\
\hline Nivel național & 24 & 22 & 22 & 23 & 25 & 5,24 & 2,40 & 2,25 & 5,43 & 5,18 \\
\hline Mun. Chișinău & 34 & 36 & 40 & 39 & 30 & 1,02 & 0,97 & 0,91 & 1,64 & 1,82 \\
\hline Mun. Bălți & 20 & 24 & 21 & 20 & 14 & 4,27 & 2,7 & 2,89 & 2,75 & 2,95 \\
\hline \multicolumn{11}{|l|}{ pe raioane: } \\
\hline Soroca & 31 & 23 & 20 & 22 & 24 & 1,87 & 1,54 & 1,60 & 2,15 & 2,42 \\
\hline Cahul & 36 & 26 & 26 & 33 & 45 & 1,41 & 2,03 & 1,82 & 2,35 & 2,94 \\
\hline Orhei & 30 & 21 & 32 & 41 & 43 & 1,37 & 2,09 & 1,96 & 2,89 & 3,28 \\
\hline Hâncești & 16 & 17 & 18 & 18 & 22 & 2,99 & 3,14 & 3,02 & 3,45 & 3,36 \\
\hline
\end{tabular}

Sursa: Elaborat de autor în baza datelor ANOFM

Analiza eficienței serviciilor privind formarea profesională a șomerilor ne arată că eficiența în termeni de rezultat cea mai înaltă a fost înregistrată în raioanele Orhei, Cahul și Hâncești. În acelaşi timp, este important de precizat că ponderile de peste $100 \%$ persoane angajate se datorează includerii aici și a şomerilor ce urmau un curs de instruire la sfârşitul anului precedent, dar au finalizat cursurile în perioada de raportare. Lider în eficiența serviciilor de formare profesională în anii analizați este raionul Orhei - 124,5\% în 2015 și câte 100\% în anii 2014 și 2018. Concomitent menționăm că, în anii 2017-2018 toți șomerii din AOFM Orhei și Hâncești au urmat un curs de formare profesională în mun. Chișinău, astfel, toate cheltuielile au fost suportate de mun. Chișinău.

\section{Tabelul 4. Eficiența serviciilor privind formarea profesională}

\begin{tabular}{|c|c|c|c|c|c|c|c|c|c|c|}
\hline & \multicolumn{4}{|c|}{$\begin{array}{c}\text { Ponderea persoanelor plasate } \\
\text { în câmpul muncii din numărul total } \\
\text { al beneficiarilor, \% }\end{array}$} & \multicolumn{4}{c|}{$\begin{array}{c}\text { Cheltuieli pe 1 persoană angajată în urma } \\
\text { serviciilor de formare profesională } \\
\text { (lei / 1 pers.) }\end{array}$} \\
\cline { 2 - 14 } & $\mathbf{2 0 1 4}$ & $\mathbf{2 0 1 5}$ & $\mathbf{2 0 1 6}$ & $\mathbf{2 0 1 7}$ & $\mathbf{2 0 1 8}$ & $\mathbf{2 0 1 4}$ & $\mathbf{2 0 1 5}$ & $\mathbf{2 0 1 6}$ & $\mathbf{2 0 1 7}$ & $\mathbf{2 0 1 8}$ \\
\hline Nivel național & 86 & 53 & 90 & 85 & 91 & 4002 & 6668 & 3716 & 3925 & 2531 \\
\hline Mun. Chișinău & 106 & 81 & 93 & 83 & 94 & 5933 & 8434 & 6332 & 7085 & 8863 \\
\hline Mun. Bălți & 80 & 82 & 96 & 81 & 80 & 5750 & 5527 & 6225 & 7940 & 8778 \\
\hline pe raioane: & & & & & & & & & & \\
\hline Soroca & 56 & 49 & 122 & 100 & 79 & 2942 & 4909 & 1823 & 1574 & 1983 \\
\hline Cahul & 75 & 66 & 75 & 91 & 86 & 8429 & 7014 & 4826 & 2571 & 3071 \\
\hline Orhei & 100 & 73 & 125 & 60 & 100 & 2538 & 3833 & 1760 & $* 0$ & $* 0$ \\
\hline Hâncești & 66 & 46 & 69 & 89 & 84 & 4306 & 8319 & 4310 & $* 0$ & $* 0$ \\
\hline
\end{tabular}

*Aprecierea eficientei în termeni de cost este mai dificilă, deoarece nu în toate raioanele se organizează cursuri de formare profesională a șomerilor. Prin urmare, înregistrarea absolvenților cursurilor de formare profesională se efectuează conform raionului unde acesta se află la evidență, iar resursele financiare alocate pentru cursuri se transferă la AOFM teritorială unde se desfășoară cursurile respective. Astfel, raportarea cheltuielilor privind formarea profesională nu coincid, în aspect teritorial, cu repartiţia resurselor conform bugetului planificat, prin urmare, aprecierea eficienței în termeni de cost este realizată cu abateri semnificative: spre exemplu, în cazul raioanelor Hâncești și Orhei, formarea profesională are loc în mun. Chișinău, astfel sumele raportate per absolvent sunt incluse în rapoartele mun. Chișinău, comparativ cu celelalte raioane.

Sursa: Elaborat de autor în baza datelor ANOFM

Cercetarea unor date mai cuprinzătoare privind evoluția profesională de mai departe a şomerilor care au absolvit cursurile de pregătire profesională, ar permite determinarea mai corectă a eficienței programelor de pregătire profesională şi perfecționarea acestora pentru atingerea efectului maxim din resursele financiare alocate. Spre regret, în rapoartele ANOFM lipsesc datele privind distribuția şomerilor în funcție de durata perioadei dintre momentul absolvirii cursurilor şi angajării 
la lucru. De asemenea, lipsesc datele privind șomerii care au urmat cursuri de pregătire profesională de mai multe ori.

Concluzii. În baza analizei efectuate, concluzionăm că rata șomajului în mun. Chișinău în anul 2018 atingea valoarea de 4,8\%, fiind cu 1,8p.p. mai înaltă față de nivelul șomajului înregistrat la nivel de țară. În baza analizei efectuate, observăm că în Chișinău nivelul șomajului continuă să se mențină la un nivel înalt, deși sunt înregistrate cele mai multe locuri libere de muncă. Programele de formare profesională nu asigură la nivelul cuvenit calificarea, recalificarea și perfecționarea şomerilor, ținând cont de cererea pieței muncii actuale.

În scopul îmbunătățirii situației pieței muncii și sporirii nivelului de ocupare mai deplină a populației se propune:

- $\quad$ ghidarea vocaţională, consiliere, formarea continuă şi orientarea profesională a populației apte de muncă;

muncii;

ridicarea calificării forței de muncă în concordanță cu abilitățile cerute pe piața

- $\quad$ asigurarea ocupării cât mai depline a populației și eliminarea oricăror forme de discriminare pe piața muncii;

- perfecționarea serviciilor de orientare în carieră pentru elevi şi studenţi prin aprecierea intereselor vocaționale şi profesionale, precum şi consilierea în alegerea ocupaţiilor; muncă. aprecierea gradului de corespundere a locurilor de muncă cu distribuția forței de

\section{Bibliografie}

1. Agenția Națională pentru Ocuparea Forței de Muncă (ANOFM). www. anofm.md.

2. Biroul Naţional de Statistică al Republicii Moldova (BNS). www.statistica.md.

3. Bîrcă A. Sporirea ocărârii forței de muncă prin flexicuritate. Materialele Conferinței Internaționale ,Asigurarea viabilității economico-manageriale pentru dezvoltarea durabilă a economiei regionale în condiţiile integrării în UE ". Bălţi, 2018, p. 70-78.

4. Legea privind ocuparea forței de muncă și protecția socială a persoanelor aflate în căutarea unui loc de muncă: nr.102-XV din 13 martie 2003. Monitorul Oficial al Republicii Moldova, 2003, nr.70-72, art. 312.

5. Pantea L. Politici de ocupare a forței de muncă: trăsături şi conţinut. Materialele Conferinței Internaționale „Performanțe într-o economie competitivă”. Institutul Internațional de Management „IMI-NOVA”. Chișinău: Impressum, 2013, p. 179. 